\title{
Factors associated to maternal mortality in severe preeclampsia in lomé (West Africa)
}

\begin{abstract}
Objectives: This study was undertaken to contribute to the reduction of maternal mortality, specifically, to identify the factors influencing maternal mortality in severe preeclampsia in Lomé (Togo, West Africa).

Material and Methods: It is a retrospective and comparative study of recorded files of 704 women with severe preeclampsia who were delivered at Sylvanus Olympio's University Hospital of Lomé from 1st January to 31st December 2013. Risk factors have been compared in two groups of patients (14 dead ones versus 690 alive ones). The data were processed by using SPSS 12.0 software. Chi-square Exact Test of Fisher and calculation of Odds Ratio have been used to establish significance $(\mathrm{p}<0.05)$ and correlation between variables.
\end{abstract}

Results: Illiterate as education level $(\mathrm{OR}=6.79 ; \mathrm{p}=0.0069)$ and gestational age under 37 weeks $(\mathrm{OR}=7.03 ; \mathrm{p}=0.037)$ had negatively influenced maternal prognosis. Systolic blood pressure over $200 \mathrm{~mm} \mathrm{Hg}(\mathrm{OR}=9.6 ; \mathrm{p}=0.0002)$ and qualitative proteinuria $>5 \mathrm{~g} / 24$ hours $(\mathrm{OR}=6.7 ; \mathrm{p}=0.01)$ were found significantly among patients who died. Stroke $(38.8 \%$ against $0 \% ; \mathrm{p}<10-8)$ and HELLP syndrome $(38.8 \%$ against $0 \% \mathrm{p}<10-5)$ were the main complications found in patients who died (respectively). Vaginal delivery was performed in $21.4 \%$ of dead patients against $57.4 \%$ of alive and had influenced significantly maternal death $(\mathrm{p}<0.02)$. Problems of reference drugs availability dominated the management aspects and were found in $4(28.6 \%)$ of dead patients against $12(1.7 \%)$ of alive ones $(p<0.0001)$.

Conclusion: Many factors associated to maternal death in severe preeclampsia were avoidable. There is a need of mass education, of more relevant medical platform in reference centers and of granting for free or for a very low cost, obstetrical emergencies care.

Keywords: severe preeclampsia, maternal mortality, hypertension pregnancy, HELLP syndrome, Togo
Volume 2 Issue 2 - 2015

\author{
Akpadza K,' Bassowa A, ${ }^{2}$ Modji SKK,' \\ Aboubakari AS, ${ }^{2}$ Fiagnon K,' Amah Biova \\ Adama-Hondegla' \\ 'Department of Gynecology and Obstetrics, University of Lome \\ Togo \\ ${ }^{2}$ Department of Gynecology and Obstetrics, University hospital \\ Center of Kara,Togo
}

Correspondence: Amah Biova Adama-Hondegla, OIPO BOX 4898 Lome, Togo, Tel 00(228)90183939.

Email rocadama@yahoo.fr

Received: March 08, 2015 | Published: April 13, 2015
Abbreviations: HELLP, hemolysis-elevated liver enzyme-low platelets; FGR, fetal growth restriction; WA, weeks of amenorrhea; PRM, proportional rate of maternal mortality by severe preeclampsia; WHO, world health organization.

\section{Introduction}

Hypertensive disorders in pregnancy are classified as the third leading cause of maternal death and the first cause of perinatal mortality. ${ }^{1,2}$ The World Health Organization (WHO) estimates that at least $16-25 \%$ of maternal deaths in developing countries result from hypertensive disorders during pregnancy, including severe preeclampsia and eclampsia. ${ }^{1}$ Despite maternal death, severe preeclampsia is also responsible for $62 \%$ of fetal growth restriction (FGR), $17 \%$ of perinatal mortality, $23 \%$ of placental abruption and $74 \%$ of anomalies detected in the various fetal monitoring..$^{1-3}$ For preeclampsia origin, some factors have been strongly incriminated as: oxidative stress, thrombosis, inadequate placental development, placental ischemia and genetic factors. ${ }^{4-6}$ Preeclampsia management is multidisciplinary and committed to an enough high cost balance. ${ }^{3}$ Its prognosis is related mainly to the quality of the established obstetrical monitoring, and technical platform. ${ }^{1,2}$ The discovery of severe preeclampsia may be inaugural or follow a moderate shape. In all cases, it marks an ultimate step in the course of the disease because decisions have to be taken in emergency to stop pregnancy, with the aim to avoid eclampsia crisis. ${ }^{7}$

In Togo, studies have focused on severe preeclampsia and its paroxysmal complications. ${ }^{8-10}$ It have been noticed that preeclampsia is likely to emerge, in teaching hospitals area in Lomé, among the first causes of maternal death. Though classical risks factors linked to maternal death in preeclampsia have been identify in literature, each local context (individual influences, cultural and health system organization) is supposed to influence the outcome of severe preeclampsia. To date, no data have been reported to the factors associated with the prognosis of severe preeclampsia in Lomé.

This study was undertaken to contribute to the reduction of maternal mortality, ${ }^{11,12}$ specifically, to identify the factors influencing maternal mortality in severe preeclampsia ${ }^{13}$ at the maternity of Sylvanus Olympio's University Hospital Center of Lomé in Togo (West Africa).

\section{Materials and methods}

This was a comparative study of records of patients admitted to the maternity of Sylvanus Olympio's University Hospital Center (department of Obstetrics and Gynecology) of Lomé with severe preeclampsia from 1st January to 31st December 2013 (1 year). Sylvanus Olympio's University Hospital Center of Lomé is the largest reference center of Togo. It is a rank "A" maternity, with a capacity of 160 beds, which is about 5,000 deliveries per year, providing full emergency obstetrical and neonatal care (full EmONC),

Data were collected by documentary review on standardized survey forms, from the registers of births, and medical records of patients. Files were selected in the archives service of gynecology and 
obstetrics, in the archives service of maternal deaths and in intensive care unit.

Severe preeclampsia was diagnosed as a new onset of:

a. Severe hypertension (systolic blood pressure $\geq 160 \mathrm{~mm} \mathrm{Hg}$ and diastolic $\geq 110 \mathrm{~mm} \mathrm{Hg})$ and proteinuria $(\geq 0.3 \mathrm{mg} / \mathrm{L}$ in 24 hours urine specimen or 1+ dipstick),

b. Moderate hypertension and severe proteinuria $(>3.5 \mathrm{~g} /$ day or +++ dipstick) associated with complications such as oliguria $(<$ $500 \mathrm{~mL} /$ day), HELLP (hemolysis-elevated liver enzyme-low platelets) syndrome, accompanied by neurological disorders (eclampsia) or abruptio placentae, fetal damage (intrauterine growth restriction, oligoamnios) after 20 weeks of gestation in a previously normotensive woman. ${ }^{7}$

Were included in this study, records' files of pregnant or parturient presenting severe preeclampsia diagnostic criteria, parturient with gestational age $\geq 20$ weeks of amenorrhea whose outcome was favorable or not and who have delivered in the service. The study focused on the comparison of two groups of patients "dead" and "alive". Socio-demographics settings, obstetrical and antenatal characteristics and several aspects of patient's management were analyzed.

\section{Operational definitions}

a. Proportional rate of maternal mortality by severe preeclampsia (PRM): It is a cause of death in overall mortality.

b. Case fatality rate (CFR): it is a proportion of patients suffering from severe preeclampsia who will die from this cause.

Proportional rate of maternal mortality by severe preeclampsia and case fatality rate (CFR) were calculated as indicated below:

$\mathrm{PRM}=$ number of deaths due to severe preeclampsia/Total number of maternal death

$\mathrm{CFR}=$ Number of deaths from severe preeclampsia during 1 year/ Number of people with severe preeclampsia during 1 year.

\section{Statistical analysis}

The data were processed with the Sphinx software. Chi 2 Test Exact of Fischer was applied and calculation of Odds Ratio have been used to establish significance ( $p$ value $<0.05$ ) and correlation between variables. The results were expressed with $95 \%$ confidence interval.

\section{Results}

General data during the study period concerning number of deliveries, total live births, total number of severe preeclampsia, number of maternal death and number of deaths related to severe preeclampsia were conserved in Table 1. There were 704 cases of severe preeclampsia out of 7561 deliveries during the period, giving a prevalence of $9.3 \%$. According to the calculations, proportional rate of maternal mortality by severe preeclampsia (PRM) and case fatality rate were respectively $18 \%$ and $2 \%$.

The socio demographical, obstetrical and antenatal characteristics of patients are shown in Table 2. None of the socio-demographical parameters had influenced maternal prognosis except education level $(\mathrm{p}=0.0069)$ and gestational age $(\mathrm{p}=0.037)($ Table 2$)$. Sixty-four point three percent $(64.3 \%)$ of dead patients were not literate against $20.9 \%$ alive patients. For gestational age $<37$ WA (weeks of amenorrhea), 11
(78.6\%) patients had died against $236(34.2 \%)$ alive. Systolic blood pressure over $200 \mathrm{~mm} \mathrm{Hg}$ was found significantly ( $\mathrm{p}=0.0002$ ) among patients who died than alive patients respectively for $57.1 \%(8)$ and $12 \%(83)$. The qualitative proteinuria was $+++(>5 \mathrm{~g} / \mathrm{L})$ in $12(85.7 \%)$ of dead patients against $340(49.3 \%)$ of alive patients $(\mathrm{p}=0.01)$.

Table I General data of the service and maternal health indicators

\begin{tabular}{ll} 
Parameters & Number \\
\hline Number of deliveries & $756 \mathrm{I}$ \\
Total live births & 7056 \\
Total number of severe preeclampsia & 704 \\
Number of maternal death in 20I3 & 77 \\
Number of deaths related to severe preeclampsia & 14 \\
\hline
\end{tabular}

Table 2 Maternal characteristics

\begin{tabular}{|c|c|c|c|c|}
\hline $\begin{array}{l}\text { Died } \\
(n=\mid 4)\end{array}$ & $\begin{array}{l}\text { Alive } \\
(n=690)\end{array}$ & $\begin{array}{l}\mathbf{P} \\
\text { value }\end{array}$ & OR & IC of OR \\
\hline N (\%) & N (\%) & & & \\
\hline
\end{tabular}

\section{Age (years)}

$\geq 35$

$<35$

$3(21.4)$

94(13.6)

0.42

$0.30-6.70$

Educational level

illiterate

9(64.3)

144(20.9)

0.0006

Literate

546(79.1)

Gravidity

Primigravida

4(28.6)

239(34.6)

0.78

primigravida

10(7I.4)

$45 I(65.4)$

Parity

\section{Nulliparous}

328(47.5)

I

nulliparous

9(64.3)

362(52.5)

Mode of admission

Admitted

4(28.6)

249(36.I)

0.77

Referred

10 (7I.4)

44I(63.9)

Gestational age (weeks)

$<37$

I I (78.6)

236(34.2)

0.001

$\geq 37$

$3(21.4)$

454(65.8)

Systolic blood pressure

$\geq 200 \mathrm{~mm} \mathrm{Hg} \quad 8(57.1) \quad 83(12)$

$<200 \mathrm{~mm} \mathrm{Hg}$ 6(42.9)

Diastolic blood pressure

\begin{tabular}{|c|c|c|c|c|c|}
\hline$\geq 110 \mathrm{~mm} \mathrm{Hg}$ & $10(71.4)$ & $328(47.5)$ & 0.1 & 2.75 & $0.78-12.15$ \\
\hline$<110 \mathrm{~mm} \mathrm{Hg}$ & $4(28.6)$ & $362(52.5)$ & & & \\
\hline \multicolumn{6}{|l|}{ Proteinuria } \\
\hline$+++(5 g / l)$ & $12(85.7)$ & $340(49.3)$ & 0.01 & 6.16 & $\begin{array}{l}1.35- \\
57.10 .\end{array}$ \\
\hline $\begin{array}{l}+ \text { or }++(\text { from } \\
0.3 \mathrm{~g} / \mathrm{l} \text { to } \mathrm{Ig} / \mathrm{l})\end{array}$ & $2(14.3)$ & $350(50.7)$ & & & \\
\hline
\end{tabular}


Several antihypertensive drugs were used in the same patient, Nicardipine as Calcium channel blocker was the antihypertensive drugs used in $8(42.1 \%)$ of dead patients against $135(11.2 \%)$ of alive patients. Stroke and HELLP syndrome were the main complications found in patients who died compared to alive patient (respectively $30.8 \%$ against $0 \%, \mathrm{p}<10-8$ and $38.8 \%$ against $0 \%, \mathrm{p}<10-5$ ). Among alive patients, eclampsia crisis in postpartum was the most found in $73.3 \%$ case. The vaginal delivery was performed in $3(21.4 \%)$ of dead patients against 396 (57.4\%) of alive and had influenced significantly $(\mathrm{p}<0.02)$ maternal prognosis. Twenty eight point six percent $(28.6 \%)$ of patients died before giving birth. Problems of reference drugs' availability dominated the management aspects (Table 3 ) and were found in $4(28.6 \%)$ of dead patients against $12(1.7 \%)$ of alive $(\mathrm{p}<0.0001)$.

Table 3 Different aspect of management

\begin{tabular}{|c|c|c|c|}
\hline & $\begin{array}{l}\text { Died } \\
(n=\mid 4) \\
n(\%)\end{array}$ & $\begin{array}{l}\text { Alive } \\
(n=690) \\
n(\%)\end{array}$ & $\begin{array}{l}P \\
\text { value }\end{array}$ \\
\hline \multicolumn{4}{|l|}{ Therapeutic used } \\
\hline \multicolumn{4}{|l|}{ Antihypertensive drugs* } \\
\hline $\begin{array}{l}\text { Clonidine by intramuscular } \\
\text { route }\end{array}$ & $7(36.8)$ & $587(48.7)$ & 0.001 \\
\hline $\begin{array}{l}\text { Alpha-methyldopa by oral } \\
\text { route }\end{array}$ & $\mathrm{I}(5.3)$ & $456(37.8)$ & $5-\mathrm{Oct}$ \\
\hline $\begin{array}{l}\text { Nicardipine by intra venous } \\
\text { route }\end{array}$ & $8(42.1)$ & $135(11.2)$ & 0.5 \\
\hline Atenolol by oral route & $0(0)$ & $I(0 . I)$ & I \\
\hline \multicolumn{4}{|l|}{ Anticonvulsants drugs } \\
\hline $\begin{array}{l}\text { Diazepam by intra venous } \\
\text { route }\end{array}$ & $6(42.9)$ & $550(79.7)$ & 0.003 \\
\hline $\begin{array}{l}\text { Magnesium sulfate by intra } \\
\text { venous route }\end{array}$ & $8(57.1)$ & $60(8.7)$ & 6-Oct \\
\hline \multicolumn{4}{|l|}{ Post natal complications* } \\
\hline Post-partum hemorrhage & $\mathrm{I}(7.7)$ & $9(10)$ & 0.18 \\
\hline Post-partum eclampsia & $\mathrm{I}(7.7)$ & $66(73.3)$ & 1 \\
\hline HELLP** syndrome & $4(30.8)$ & $0(0)$ & $5-\mathrm{Oct}$ \\
\hline Stroke & $5(38.8)$ & $0(0)$ & $8-O c t$ \\
\hline chronic renal failure & $\mathrm{I}(7.7)$ & $0(0)$ & 0.01 \\
\hline \multicolumn{4}{|l|}{ Delivering route } \\
\hline Vaginal delivery & $3(2 \mid .4)$ & $396(57.4)$ & 0.02 \\
\hline Cesarean section & $7(50.0)$ & $294(42.6)$ & 0.59 \\
\hline No childbirth & $4(28.6)$ & $0(0)$ & 7-Oct \\
\hline \multicolumn{4}{|c|}{ Problems related to the emergency care* } \\
\hline $\begin{array}{l}\text { Financial problems of the } \\
\text { patient's family }\end{array}$ & $4(28.6)$ & $118(17.1)$ & 0.29 \\
\hline $\begin{array}{l}\text { Drugs and equipment not } \\
\text { available }\end{array}$ & $4(28.5)$ & $12(1.7)$ & 0.0001 \\
\hline $\begin{array}{l}\text { Family's opposition to medical } \\
\text { decision }\end{array}$ & $0(0)$ & $7(1)$ & I \\
\hline
\end{tabular}

*A same patient could have received several drugs and had several complications.

**HELLP syndrome: Hemolysis, Elevated Liver Enzymes Low Platelets Syndrome.

\section{Different delay between diagnosis and management}

Antihypertensive drugs were administered immediately on admission to $14.3 \%$ among patients died and $27.7 \%$ among survivors. Before the first hour, the delivery occurred in $50 \%$ of dead patients against $24.9 \%$ of alive (Table 4 ).

Table 4 Different delay between diagnosis and management

$\begin{array}{lll}\text { Died (14) } & \text { Alive (690) } & \text { P value } \\ \text { n (\%) } & n(\%) & \end{array}$

Delay between diagnosis and administration of antihypertensive drugs

$\begin{array}{lccc}\text { Immediately }(0 \mathrm{~min}) & 2(14.3) & 191(27.7) & 0.37 \\ \leq 30 \text { minutes } & 2(14.3) & 364(52.8) & 0.01 \\ \text { 30-60minutes } & \mathrm{I}(7.1) & 5 \mathrm{I}(7.3) & \mathrm{I} \\ \geq 60 \text { minutes } & 9(64.3) & 84(12.2) & 9.10-6\end{array}$

Delay between diagnosis and childbirth

\begin{tabular}{llll}
$<60$ minutes & $7(50)$ & $\mathrm{I} 72(24.9)$ & 0.05 \\
$60-120$ minutes & $2(\mid 4.3)$ & $85(\mid 12.4)$ & 0.63 \\
I20-180minutes & $\mathrm{I}(7.1)$ & $6 \mathrm{I}(8.8)$ & $\mathrm{I}$ \\
$>180$ minutes & $4(28.6)$ & $372(53.9)$ & $0.0 \mathrm{I}$ \\
\hline
\end{tabular}

\section{Discussion}

We investigated factors associated to maternal death in severe preeclampsia at Sylvanus Olympio's University Hospital Center of Lomé. There were 704 cases of severe preeclampsia out of 7561 deliveries during the period, giving a prevalence of $9.3 \%$. Indeed several data of the literature shows that preeclampsia complicate $5 \%$ to $10 \%$ of all pregnancy as well as in developed and developing countries. ${ }^{14,15}$ In our series, proportional rate of maternal mortality by severe preeclampsia (PRM) and Case Fatality Rate were respectively $18 \%$ and $1.99 \%$. This fatality rate is higher than the finding of $0.38 \%$ by Sawhney et al., ${ }^{16}$ but lower than $29.63 \%$ reported by Ezugwu et al.,${ }^{17}$ in Nigeria. Bilano et al., ${ }^{18}$ in a regional survey about preeclampsia found that fatality rate of severe preeclampsia in Africa was $1.39 \%$ against $0.05 \%$ and $0.68 \%$ respectively in Latin America and Asia. These results demonstrate the impact of severe preeclampsia in maternal mortality and the contrast between Africa and other continents. This also shows the link between maternal mortality and socio-economic levels. Generally, maternal mortality in severe preeclampsia is related to socio-economic level of the region ${ }^{19}$ and the maternal condition on admission and associated complications. ${ }^{16}$

None of the socio-demographical parameters as age, gravidity, gestity and mode of admission, had influenced maternal prognosis except education level, gestational age and severity of the systolic blood pressure during admission. Indeed $964.3 \%$ of dead patients were not literate against $20.9 \%$ of alive patients $(\mathrm{p}<0.0006)$. According to Asamoah et al. ${ }^{19}$ in Ghana, maternal mortality is inversely proportional to the level of education. It appears that low socio educational status was counted among the first causes of maternal death in preeclampsia/ eclampsia.

Gestational age under 37 weeks of amenorrhea was significantly $(\mathrm{p}<0.05)$ higher among dead patient compared with alive patient. Systolic blood pressure over $200 \mathrm{~mm} \mathrm{Hg}$ was found significantly higher 
$(\mathrm{p}<0.001)$ among patients who died than alive patients respectively for $57.1 \%$ and $12 \%$ and the qualitative proteinuria was higher $(>5 \mathrm{~g} / \mathrm{L})$ in $85.7 \%$ of dead patients against $49.3 \%$ of alive patients. This indicates the severity of the complications of the disease in patients who died. Bushnell in USA has found that $54 \%$ of hemorrhagic stroke mortality is due to severe hypertension ${ }^{20}$ in preeclampsia. In the series of Newman et al. ${ }^{21}$ maternal and neonatal morbidity in three groups of patients with severe preeclampsia were compared on the base of 24 hours proteinuria. According to Haddad et al. ${ }^{22}$ study, proteinuria more than $5 \mathrm{~g} / 24$ hours would be associated to $48.8 \%-53.7 \%$ of severe hypertension, $20.9 \%$ of HELLP syndrome and $2.3 \%$ to $7.3 \%$ of eclampsia and from 14 to $17.1 \%$ of fetal death. These results reflect the bad prognosis of increased proteinuria. Increased proteinuria is proportional to the onset of maternal and fetal complications. It well known that the majority of deaths related to preeclampsia could be avoided by effective antenatal care and early deliveries of the women. Indeed, the maternity of the University Hospital Center Sylvanus Olympio in Lomé is a reference center; more patients in extreme emergencies come to fail in the service. Their low educational and socioeconomic levels probably accentuated the delay to the first emergency care. In this study we have little information in patients' files regarding the frequency of antenatal visits, the time of appearance of preeclampsia and of the high blood pressure duriing pregnancy. In our series, strokes were responsible for $52.9 \%$ of deaths followed by HELLP syndrome in $29.4 \%$.

The same observation has been made in India by Sawhney et al., ${ }^{16}$ and by Moodley et al., ${ }^{23}$ in South Africa according to them, cerebral complications including stroke were, the leading causes of maternal death respectively in $52.4 \%$ and $45.5 \%$. Among patients who died, antihypertensive drugs and anticonvulsants were administered respectively in $21.4 \%$ and in $21.5 \%$ of cases beyond the first hour. By cons, in alive patients, antihypertensive and anticonvulsants were administered respectively $77 \%$ and $78.1 \%$ of cases in the first 15 minutes of admission. This shows retardation in care administration of dead patients. This is explained by the lack of emergency medical kit. Indeed, every drug or prescribed equipment was purchased by the patient family before, thus anticonvulsants used in the management of severe preeclampsia were not available in the service for immediate use. Magnesium sulfate and Nicardipine, as reference drugs were constantly lacking in the hospital pharmacy and in some other ones in the city. To these factors, was associated precarious socioeconomic status of patients? So in first intention, medical staff relied on clonidine injection or methyldopa tablets often available to the patients on arrival. Nicardipine and magnesium sulfate were also administered but often very late (When the patient's family brought it after). This could explain the significant relationships found between maternal deaths and the use of these three drugs.

As expected, $50 \%$ of dead patients in our series had given birth before the 1 st hour against $24.9 \%$ of alive patients. This is due to the divergence of delivery ways observed in our series. Indeed $50 \%$ of dead patients had undergone a caesarean section and the majority of the alive patient $(57.4 \%)$ was delivered vaginally. The high rate of cesarean observed in both died and alive patients were due to the emergency of uterine evacuation, which is the only effective treatment for severe preeclampsia.

\section{Conclusion}

The factors associated to maternal death of in severe preeclampsia, in this study; seem to be related to poor socioeconomic status of patients, low educational level the severity of high blood pressure. There is a real need of the young girl literate education, of the information of the people on this affection's gravity. There is also a need of more relevant medical platform in reference centers and granting for free or very low cost obstetrical and neonatal emergencies care.

\section{Acknowledgments}

None.

\section{Conflicts of interest}

The authors declare there is no conflict of interests.

\section{References}

1. Édouard D, Prééclampsie Éclampsie. Encycl Méd Chir, AnesthésieRéanimation, 36-980-A-10, Obstétrique, 5-071-B-30; 2003. 15 p.

2. Beaufils M. Hypertensive disorders of pregnancy. Rev Med Interne. 2002;23(11):927-938.

3. Diemunsch P, Langer B, Noll E. Principes généraux de la prise en charge hospitalière de la prééclampsie. Ann Fr Anesth Reanim. 2010;29(4):e51e58.

4. Herse F, LaMarca B. Angiotensin II type 1-Receptor Autoantibody (AT1-AA) -mediated pregnancy hypertension. Am J Reprod Immunol. 2013;69(4):413-418.

5. Conde-Agudelo A, Romero R, Kusanovic JP, et al. Supplementation with vitamins $\mathrm{c}$ and $\mathrm{e}$ during pregnancy for the prevention of preeclampsia and other adverse maternal and perinatal outcomes: a systematic review and meta analysis. Am J Obstet Gynecol. 2011;204(6):503.e1-503.12.

6. Queensland Maternity and Neonatal Clinical Guidelines Program. Hypertensive disorders of pregnancy. MN10.13-V4-R15; 2010. p. 1-24.

7. Magee LA, Pels A, Helewa M, et al. Diagnosis, Evaluation, and Management of the Hypertensive Disorders of Pregnancy: Executive Summary. J Obstet Gynaecol Can. 2014;36(5):416-438.

8. Baragou S, Goeh-Akue E, Pio M, et al. Hypertension artérielle et grossesse à Lomé (Afrique sub-saharienne): aspects épidémiologiques, diagnostiques et facteurs de risque. Annales de cardiologie et d'angéiologie. 2014;63(3):145-150.

9. Akpadza K, Baeta S, Neglo Y, et al. L'hématome retroplacentaire (HRP) à la clinique de gynécologie-obstétrique du CHU Tokoin-Lomé (Togo) de 1988 à 1992. Med Afr Noire. 1996;43(6):342-347.

10. Akpadza K, Baeta S, Kotor KT, et al. L'éclampsie à la clinique de gynécologie-obstétrique du CHU Tokoin-Lomé. Med Afr Noire. 1996;43(3):13-16.

11. Les indicateurs de la santé reproductive et de la mortalité.

12. Michel E, Jougla E, Hatton F, et al. Principaux indicateurs de mortalité.

13. Organisation Mondiale De La Sante. Classification statistique internationale des maladies et des problemes de sante connexes CIM-10. 2008.

14. Ghulmiyyah L, Sibai B. Maternal Mortality From Preeclampsia/ Eclampsia. Seminars in perinatology. 2012;36(1):56-59.

15. Osungbade KO, Ige OK. Public health perspectives of preeclampsia in developing countries: implication for health system strengthening. $J$ Pregnancy. 2011.

16. Sawhney H, Aggarwal N, Biswas R, et al. Maternal Mortality Associated with Eclampsia and Severe Preeclampsia of Pregnancy. $J$ Obstet Gynaecol Res. 2000;26(5):351-356. 
17. Ezugwu EC, Onah HE, Ezugwu FO, et al. Maternal Mortality in a Transitional Hospital in Enugu, South East Nigeria. Afr J Reprod Health. 2009;13(4):67-72

18. Bilano VL, Ota E, Ganchimeg T, et al. Risk factors of pre-eclampsia/ eclampsia and its adverse outcomes in low- and middle-income countries: a WHO secondary analysis. PLoS One. 2014;9(3):e91198.

19. Asamoah BO, Moussa KM, Stafström M, et al. Distribution of causes of maternal mortality among different socio-demographic groups in Ghana; a descriptive study. BMC Public Health. 2011;11:159.

20. Bushnell C, Chireau M. Preeclampsia and Stroke : Risks during and after Pregnancy. Stroke Res Treat. 2011;2011:858134.
21. Newman MG, Robichaux AG, Stedman CM, et al. Perinatal outcomes in preeclampsia that is complicated by massive proteinuria. Am J Obstet Gynecol. 2003;188(1):264-268.

22. Haddad B, Masson C, Deis S, et al. Criteria of pregnancy termination in women with preeclampsia. Ann Fr Anesth Reanim. 2010;29(4):e59-e68.

23. Moodley J. Maternal deaths associated with hypertension in south Africa: lessons to learn from the saving Mothers report, 2005-2007. Cardiovasc J Afr. 2011;22(1):31-35. 